\title{
Role of Lectins and Lipopolysaccharides in the Recognition Process of Specific Legume-Rhizobium Symbiosis
}

\author{
Goro Kato, Yoshiharu Maruyama and Michinori NaKamura \\ Department of Agricultural Chemistry, Faculty of Agriculture, \\ The University of Tokyo, Bunkyo-ku, Tokyo
}

Received December 25, 1978

\begin{abstract}
Rhizobium japonicum and $R$. leguminosarum combined specifically with lectins of host plants, and lipopolysaccharides with the strongest inhibitory activity towards the hemagglutinating reaction of host plants lectins were extracted and purified from the two Rhizobial species. Moreover, they inhibited the binding reaction between lectins and bacterial cells. These results support the lectin theory that the interaction between lectins of host plants and Rhizobium is the key to the mechanism of the host specificity in Rhizobium-legume symbiosis, and that the lectin-receptor of Rhizobial cells exists in the cell surface lipopolysaccharides.
\end{abstract}

It is well known that there is a rather strict specificity between Rhizobial species and the host plants in the symbiotic nitrogen fixation by leguminous plants. ${ }^{1,2)}$ This specificity may be determined with Rhizobial cells to recognize the root haris of the corresponding leguminous hosts.

Carbohydrates on the cell surface can function in the intercellular recognition process ${ }^{3 \sim 5}$, and the case between Rhizobium and root hair cells may not be an exception. Therefore, it is assumed that the bacterial recognition of its host is related to the carbohydrates on its cell surface and the Rhizobial species with different host specificity have different cell surface carbohydrates respectively. Exopolysaccharide or lipopolysaccharide, both located on the cell surface of Rhizobial cells, may function in the host recognition process.

Many of the leguminous plants are known to contain lectins, which bind specifically with suitable sugar or sugar chains. Since Schmidt and Bohlool ${ }^{6)}$ showed that soybean lectin binds specifically to $R$. japonicum, but

* Abbreviations: lipopolysaccharide, LPS; exopolysaccharide, EXPS; cetavlon-ethanol precipitate, CEP; $0.02 \mathrm{M}$ phosphate buffer- $0.155 \mathrm{M}$ saline, PBS; peak I, P-I; peak II, P-II; sodium dodecyl sulfate, SDS; periodic acid-Schiff, PAS; soybean lectin, SBA; pea lectin, PA; fluorescein isothiocyanate, FITC; 2keto-3-deoxyoctonate, KDO; concanavaline A, Con A; wheat germ agglutinin, WGA. not to other Rhizobial species, there have appeared several papers ${ }^{7 \sim(3)}$ supporting the lectin hypothesis. However, there is only a few reseaches ${ }^{8, y, 14,15)}$ on the nature of the lectinreceptor of Rhizobial cells. This paper deals with this problem and it is shown that the interaction between the lectin and lipopolysaccharide may be one of the determinative steps in the establishment of root nodule formation in the symbiotic nitrogen fixation of leguminous plants.

\section{MATERIALS AND METHODS}

Materials. Rhizobial strains. Rhizobium japonicum strains 509,5033 and 501 and $R$. leguminosarum strains $J 357$ and $J 2080$ were obtained through the courtesy of Dr. Tsuru, the Institute of Agricultural Technology, the Ministry of Agriculture and Forestry.

Leguminous seeds. Soybean (Glycine max, var. Shiratori) and pea (Pisum satirum. var. Sanjûnichikinuzaya and var. Waisei-akabana-kinuzaya) were purchased from Takii Seeds Co., Tokyo.

Maintenance and cultivation of the bacteria. The agar medium for maintenance consisted of $0.5 \mathrm{~g}$ of dipotassium hydrogen phosphate, $0.2 \mathrm{~g}$ of magnesium sulfate heptahydrate, $0.1 \mathrm{~g}$ of sodium chloride, $3.0 \mathrm{~g}$ of calcium carbonate, $1.0 \mathrm{~g}$ of yeast extract, $10 \mathrm{~g}$ of mannitol and $15 \mathrm{~g}$ of agar per liter. R. japonicum and $R$. leguminosarum were maintained on agar slants at $11^{\circ} \mathrm{C}$.

The bacteria were cultivated with shaking (150 $200 \mathrm{rpm}$ ) at $25^{\circ} \mathrm{C}$ in a liquid medium containing (per 
liter): dipotassium hydrogen phosphate $(0.6 \mathrm{~g})$, potassium dihydrogen phosphate $(0.2 \mathrm{~g})$, sodium chloride $(0.1 \mathrm{~g})$, potassium nitrate $(0.4 \mathrm{~g})$, magnesium sulfate pentahydrate $(0.1 \mathrm{~g})$, calcium nitrate $(0.05 \mathrm{~g})$, yeast extract $(1 \mathrm{~g})$, mannitol $(10 \mathrm{~g})$, boric acid $(1 \mathrm{mg})$, zinc sulfate heptahydrate $(1 \mathrm{mg})$, cupric sulfate pentahydrate $(0.5 \mathrm{mg})$, manganese chloride $(0.5 \mathrm{mg})$, ferric-ethylenediaminetetraacetic acid ( $1 \mathrm{mg}$ iron) and sodium molybdate $(0.01 \mathrm{mg})$.

Test for nodulating activity of Rhizobium. The growth pouch (Scientific Products, Div. of American Hospital Supply Corp.) containing the nitrogen-free nutrient solution ${ }^{16)}$ was autoclaved $\left(120^{\circ} \mathrm{C}, 20 \mathrm{~min}\right)$ and one or two surface-sterilized seeds ${ }^{17)}$ were set on. After germination in the dark at $25^{\circ} \mathrm{C}$, the pouch was moved into the biotron (daytime $25^{\circ} \mathrm{C}$, nighttime $20^{\circ} \mathrm{C}$, natural light). Four $\mathrm{ml}$ of Rhizobium suspension (approximately $10^{7} \sim 10^{8}$ cells $/ \mathrm{ml}$ ) was aseptically inoculated to soybeans at eight to ten days and to peas at six to eight days respectively, after the germination. They were grown together with plants (controls) without inoculation.

\section{Isolation and purification of Rhizobial cell surface lipo- polysaccharide (LPS*).}

(1) Pretreatment of bacteria and isolation of exopolysaccharide (EXPS). Rhizobia collected from the liquid shaking culture (R. japonicum, 7 days; $R$. leguminosarum, 4 to 5 days) were suspended in $0.155 \mathrm{M}$ saline $(30 \mathrm{ml}$ per $5 \mathrm{~g}$ of wet cells) and washed by centrifugation $(20,000 \times g, 10 \mathrm{~min})$. Washing was repeated until no sugar was detected in the supernatant. The combined supernatants were sterilized with a membrane filter and then dialyzed against water. The resulting solution was stored at $4^{\circ} \mathrm{C}$.

(2) Isolation of LPS. LPS was extracted according to the method of Westpha118) by adding an equal volume of $90 \%$ phenol to the suspension of washed cells (obtained under (1)) and stirring the mixture at $65 \sim$ $70^{\circ} \mathrm{C}$ for $10 \sim 20 \mathrm{~min}$. The extraction was repeated 2 times. After cooling, the emulsion was centrifuged and the combined aqueous layers were dialyzed against water.

(3) Cetavlon treatment and ethanol precipitation. Crude LPS obtained above was concentrated under reduced pressure $\left(35 \sim 40^{\circ} \mathrm{C}\right)$ and then made to a $0.5 \sim 1 \%$ LPS solution in $0.25 \mathrm{~m}$ saline. Cetavlon (cetyltrimethyl-ammonium bromide) was added gradually to the stirred solution to make a $1.5 \%$ solution and then the mixture was stirred for further $10 \mathrm{~min}$. The precipitate formed was removed by centrifugation and the supernatant was poured into ten volumes of ethanol. It was stirred for $30 \mathrm{~min}$ at $4^{\circ} \mathrm{C}$ and then left still for $2 \mathrm{hr}$. Precipitated LPS was collected by centrifugation, dissolved in water, and dialyzed. The CEP solution obtained was stored at $4^{\circ} \mathrm{C}$.

(4) DNase-RNase treatment. Crude LPS (obtained under (2)) was treated with DNase and RNase (Sigma, bovine pancreas, each $10 \sim 100 \mu \mathrm{g} / \mathrm{ml})$ in $0.05 \mathrm{M}$ Trishydrochloric acid buffer $(\mathrm{pH} 7.5)$ containing $0.01 \mathrm{M}$ magnesium chloride at $37^{\circ} \mathrm{C}$ for $16 \mathrm{hr}$. After the treatment, the reaction mixture was dialyzed against water and centrifuged to remove any precipitate formed.

Gel filtration. Sepharose 6B (Pharmacia Fine Chemicals) was equilibrated with PBS ( $\mathrm{pH} \mathrm{7.0)}$ and the partially purified LPS (obtained under (3) or (4)) was applied to the column, followed by elution with PBS at $4^{\circ} \mathrm{C}$. Total carbohydrate was measured in each fraction and sugar-containing fractions were collected and dialyzed against water. The resulting solutions (P-I and P-II) were concentrated under reduced pressure and stored as a solution or as a lyophilized preparation at $4^{\circ} \mathrm{C}$.

SDS-polyacrylamide gel electrophoresis of LPS.19) After the heat treatment of LPS with a disintegration reagent $(10 \mathrm{~mm}$ Tris buffer, $\mathrm{pH} 8,1 \mathrm{~mm}$ EDTA, $4 \%$ SDS, $30 \%$ sucrose, $2.5 \%$ dithioerythritol) for $5 \mathrm{~min}$ at $100^{\circ} \mathrm{C}$ according to Jann et al., LPS $(100 \mu \mathrm{g})$ was subjected to SDS- polyacrylamide gel electrophoresis at $6 \mathrm{~mA}$ per gel at room temperature and sugar was located by the PAS method. ${ }^{20)}$

\section{Extraction and purification of lectins}

Soybean lectin $(S B A){ }^{21)}$ Ground soybean seeds were defatted by $\mathrm{n}$-hexane and extracted with $0.155 \mathrm{M}$ saline $(250 \mathrm{ml}$ per $50 \mathrm{~g}$ powder). The extract was fractionated with ammonium sulfate $(0.4 \sim 0.8$ saturation) to prepare crude SBA.

Crude SBA $(0.5 \sim 1 \mathrm{~g})$ was purified by affinity chromatography on a column $(2.5 \times 20 \mathrm{~cm})$ of affinity adsorbent equilibrated with PBS containing $0.02 \%$ sodium azide. SBA was eluted specifically with $0.2 \mathrm{M} \mathrm{D}$ galactose in the same buffer. Two affinity adsorbents were used: one was aminoethyl Bio-Gel P-150 (BioRad Laboratories) coupled with lactose monohydrate by the method of Gray et al. ${ }^{22}$ and the other Sepharose $6 \mathrm{~B}$ treated with $0.2 \mathrm{M}$ hydrochloric acid. ${ }^{23)}$

Pea lectin $(P A) .{ }^{24)}$ Ground pea seeds were extracted with water ( 31 per $240 \mathrm{~g}$ powder) and the protein precipitated at the isoelectric point ( $\mathrm{pH} 4.6)$ was removed. The protein remaining in the supernatant was fractionated with ammonium sulfate $(0 \sim$ 0.6 saturation) to prepare crude PA. Crude PA (about $1.5 \mathrm{~g}$ ) was applied to a Sephadex G-100 column $(3.4 \times 25 \mathrm{~cm})$ equilibrated with PBS and the column was washed with PBS. PA was eluted by $0.2 \mathrm{M} \mathrm{D}$-glucose in PBS.

Other lectins. Purified Con A and WGA were gifted by Dr. Y. Nagata, the Institute of Applied Microbiology, the University of Tokyo, Bunkyo-ku, Tokyo. 
Polyacrylamide gel electrophoresis of lectins. According to the method of Davis et al. ${ }^{25)}$, electrophoresis was carried out in $7.5 \%$ polyacrylamide gel ( $\mathrm{pH} \mathrm{9.4)}$ by applying $10 \sim 50 \mu \mathrm{g}$ sample and $3 \mathrm{~mA}$ per gel at $4^{\circ} \mathrm{C}$. Protein was dyed with Brilliant Coomassie Blue. ${ }^{203}$

Assay of hemagglutinating activity of lectins. By using an equal volume of $3 \%$ trypsinized human erythrocyte suspension of type $A$ and $0.1 \%$ lectin (freezedried) solution in $0.155 \mathrm{M}$ saline, the activity of lectin was determined as the maximum dilution multiple $\left(2^{2}\right.$, titer) of the lectin solution which hemagglutination was recognized by the serial double dilution method.

Preparation of fluorescein isothiocyanate (FITC) labeled lectin. Fifty $\mu \mathrm{g}$ of FITC per mg of lectin was dissolved in $1 \mathrm{ml}$ of $0.5 \mathrm{M}$ sodium carbonate buffer (pH 9.5) and the solution was immediately added to nine volumes of $1 \%$ lectin solution. The mixture was stirred gently for one hour at room temperature and then at $4^{\circ} \mathrm{C}$ for $18 \mathrm{hr}$. The reaction mixture was then applied to a column $(2.5 \times 40 \mathrm{~cm})$ of Bio-Gel P-6 equilibrated with PBS ( $\mathrm{pH} 7.0$ ) and eluted by the same buffer. The absorbance of the eluate at 280 and $500 \mathrm{~nm}$ was measured and fractions of labeled lectin were collected and stored frozen.

Binding reaction between fuorescent lectins and Rhizobia. Fully grown Rhizobia were suspended in PBS and to $0.5 \mathrm{ml}$ of this suspension $\left(10^{\circ}\right.$ cells $\left./ \mathrm{ml}\right)$ was added $1.5 \mathrm{ml}$ of the fluorescent lectin solution $(0.1 \sim$ $0.4 \%$ or $1.5 \mathrm{ml}$ of PBS as a control. The mixture was incubated in a shaker at $30^{\circ} \mathrm{C}$ for $30 \mathrm{~min}$, and the bacteria were washed by centrifugation with PBS and washing was repeated until unreacted lectin was removed completely. The washed cells were smeared on a slide glass, air-dried, mounted in glycerol diluted ten times with $0.5 \mathrm{M}$ sodium carbonate buffer ( $\mathrm{pH}$ 9.5) and then examined under a fluorescent microscope (Olympus) equipped with $\mathrm{HBO}-100$ lamp, using UG-1 exciter filter and $\mathrm{L} 435$ absorbing filter or equipped with AHL-250 lamp using BG-12 exciter filter, FY3 and FY5 absorbing filter.

Measurement of inhibitory activity against the hemagglutinating reaction of lectin. Lectin solution should be assayed for hemagglutinating activity just before use, and it should be adjusted at a titer of 4 . To double dilution series in $0.155 \mathrm{M}$ saline solution of the sample to be tested was added an equal volume of the lectin solution and the mixture was left still for $2 \mathrm{hr}$ at room temperature. Then, one volume of $4 \%$ trypsinized human A type erythrocyte suspension was added to two volumes of this mixture in order to assay the hemagglutinating activity. The inhibitory activity was expressed as the minimum concentration of the sample for complete inhibition of the hemagglutinating activity of the lectin solution.

\section{Quantitative analysis}

Determination of total carbohydrate. Total carbohydrate was measured by the phenol-sulfuric acid method ${ }^{27)}$ using glucose as a standard.

Determination of 2-keto-3-deoxyoctonate (KDO). The sample was hydrolyzed in $0.01 \mathrm{~N}$ sulfuric acid in a boiling water bath for $30 \mathrm{~min}$ and then neutralized with barium hydroxide. The precipitate was removed by centrifugation and then KDO in the supernatant was determined by the periodate-thiobarbituric acid method, ${ }^{23)}$ with ammonium $\mathrm{KDO}$ (Sigma) as a standard. When the sample contains DNA, 2-deoxyribose would give the color (the maximum absorption for 2-deoxyribose is at $532 \mathrm{~mm}$ and that for $\mathrm{KDO}$ is at $549 \mathrm{~nm}$ ); therefore the amount of KDO was obtained by measuring the absorbance at $532 \mathrm{~nm}$ and $549 \mathrm{~nm}$.

Determination of nucleic acid. The amount of nucleic acid was shown by $\mathrm{OD}_{280}$ of the sample multiplied by the total volume $(\mathrm{ml})$ of the sample and expressed as $\mathrm{E}_{280}$. The existence of nucleic acid in the sample was assayed by the ratio of $\mathrm{OD}_{260}$ to $\mathrm{OD}_{230}$.

Determination of protein. The amount of protein in the sample was determined either by the absorbance at $280 \mathrm{~nm}$ or by the Lowry method ${ }^{29)}$ with bovine serum albumin as a standard.

\section{RESULTS}

\section{Extraction and purification of LPS}

Since Rhizobia produced much exopolysaccharide, this was removed by washing the cells with $0.155 \mathrm{M}$ saline prior to extraction of LPS. The amount of total carbohydrate in the aqueous layer obtained by the Westphal method was 50 to 100 times as much as that in the phenol layer.

Since the crude extract contains, in addition to LPS, nucleic acids, exopolysaccharides and lipid A-free polysaccharide degradation products of LPS, LPS was purified by removing these materials, using $\mathrm{KDO}$, which is specific and characteristic to LPS, as an indicator. Nucleic acids were removed by cetavlonethanol treatment or DNase-R Nase treatment, and the residual nucleic acids and lower molecular weight polysaccharides were removed by gel filtration on Sepharose $6 \mathrm{~B}$.

Table I summarises the purification of LPS from $41 \mathrm{~g}$ wet wt. of $R$. japonicum 509 . By gel filtration of LPS on Sepharose 6B (Fig. 1), two major carbohydrate-containing peaks were obtained; P-I seemed to have a molecular 
TABle I. PURIfication OF LPS From $R$. japonicum 509

\begin{tabular}{lcrrrrrr}
\hline $\begin{array}{c}\text { Purification } \\
\text { step }\end{array}$ & $\begin{array}{c}\mathrm{TC}^{a} \\
(\mu \mathrm{mol})\end{array}$ & $E_{280}$ & $\mathrm{OD}_{280} / \mathrm{OD}_{230}$ & $\mathrm{TC} / \mathrm{KDO}$ & $E_{280} / \mathrm{KDO}$ & \multicolumn{2}{c}{ KDO } \\
\hline Crude LPS & 2111 & 8512 & 1.6 & 8.9 & 35.8 & 238 & 100 \\
CEP & 1280 & 288 & 0.7 & 7.1 & 1.6 & 180 & 76 \\
P-I & 197 & 45 & 0.1 & 1.8 & 0.4 & 110 & 46 \\
P-II & 363 & 16 & 0.1 & 35.7 & 1.6 & 10 & 4 \\
\hline
\end{tabular}

a TC, total carbohydrate.

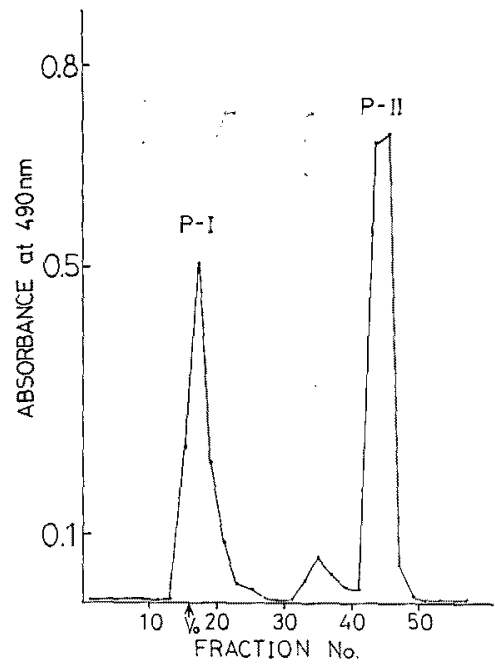

FIG. 1. Gel Filtration of LPS from R. japonicum 509 on Sepharose 6B.

The column was eluted with PBS ( $\mathrm{pH} 7.0)$. Each fraction $(6 \mathrm{ml})$ was assayed for total carbohydrate by the phenol-sulfuric acid method at $490 \mathrm{~nm}$.

weight larger than 1,000,000 and P-II seemed to be polysaccharides of lower molecular weight. P-I seemed to be a purified preparation of LPS free of nucleic acids or other polysaccharides, judging from its macromolecular state (LPS aggregates in aqueous solution to become a macromolecule), the ratio of $\mathrm{OD}_{260}$ to $\mathrm{OD}_{230}$ and the molar ratio of total carbohydrates to KDO (approximately four times as great as that of CEP). P-II may be a mixture of polysaccharides including polysaccharide degradation products of LPS, because this fraction contains a small amount of $\mathrm{KDO}$.

$S D S$-polyacrylamide gel electrophoresis of LPS $(P-I)$

The chemical heterogeneity of LPS (P-I) was analysed ${ }^{19)}$ by SDS-polyacrylamide gel electrophoresis after dissociating macromole-

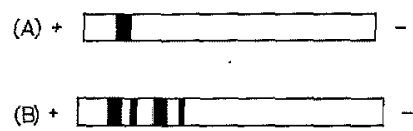

FIG. 2. Patterns of SDS-Polyacrylamide Gel Electrophoreses with $\mathbf{P}-\mathbf{I}$.

(A) P-I obtained from R.japonicum 509; (B) P-I obtained from R.leguminosarum $\mathbf{J} 357$.

cular LPS.

The P-I obtained from $R$. japonicum 509 gave only one band, but the P-I obtained from $R$. leguminosarum $\mathrm{J} 357$ gave two major and two minor bands (Fig. 2). The latter result may be interpreted as showing that the P-I from $R$. leguminosarum $\mathrm{J} 357$ contains four kinds of LPS molecules aggregating mutually; however, there is a possibility that the preparation is not sufficiently purified. Therefore, further study is needed to establish the purity of this preparation.

\section{Extraction and purification of lectins}

Lectins were extracted from seeds of soybean and pea. In analysis of the purified lectins with polyacrylamide gel electrophoresis, SBA gave one major band and three minor bands and PA gave two bands. Both results corresponded to the reports ${ }^{24,30,31)}$ which showed the existence of isolectins in soybean and pea seeds.

Binding reaction between lectin and Rhizobium

In order to confirm the hypothesis that lectin obtained from the seeds of the host plant binds specifically with the corresponding strains of Rhizobium, the lectin labeled with FITC was mixed with Rhizobia and bacterial cells were observed under a fluorescent microscope. 
TABle II. BINDING of Strains of $R$. japonicum AND R. leguminosarum WITH LECTINS AND INFECTIVITY

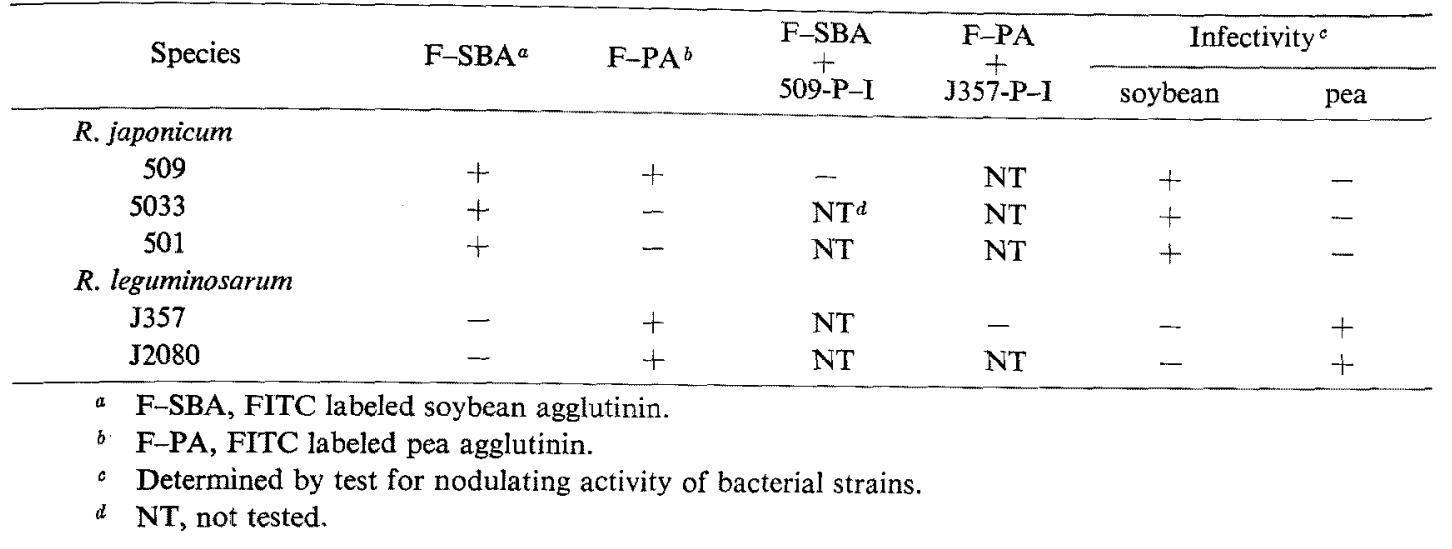

Table II shows the results of the binding reaction between 5 strains of $R$. japonicum and $R$. leguminosarum on the one hand and SBA and PA on the other, in addition to the infectivity of these bacterial strains to the host plants.

All of the three $R$. japonicum strains infected soybean roots and bound to F-SBA as well; two strains did not bind to F-PA.

Both of the two strains of $R$. leguminosarum infected pea roots and bound to F-PA; these did not bind to F-SBA.

\section{Interaction between $P-I$ and lectin}

The host-symbiont specificity between leguminous plants and corresponding Rhizobial strains is well confirmed by the cross-inoculation test. Some workers showed that lectins from the host plants might be responsible for this specificity. ${ }^{6 \sim 9)}$ If this assumption is correct, there might also be specific lectin-receptors on the cell surface of corresponding Rhizobia. It is possible that cell surface polysaccharides of Rhizobium, especially LPS, may play the role of lectin-receptor in this specific cell-cell recognition phenomena. This possibility was examined as follows.

Inhibitory activity of $P-I$ towards hemagglutinating activity of lectins. By measuring the inhibitory activity against the hemagglutinating reaction of a lectin, it is possible to know if a certain sugar binds to lectin or not, and also the intensity of the reactivity. Accordingly, the inhibitory activity against SBA of CEP, P-I and P-II obtained from $R$. japonicum 509 as well as $\mathrm{N}$-acetyl-D-galactosamine and $\mathrm{D}$ galactose, specific sugars to SBA, were measured. The results are shown in Table III. The inhibitory activity of P-I, the purified LPS, was approximately four times as great as that of CEP (partially purified LPS). This corresponded to the degree of purification as shown by the molar ratio of total carbohydrate to KDO (1.8 for $\mathrm{P}-\mathrm{I}$ and 7.1 for CEP; see Table I). This result shows that LPS (P-I) binds to lectin and inhibits the activity of it. P-II has a much weaker inhibitory activity than that of P-I. P-I showed extremely strong inhibitory activity in comparison with $\mathrm{N}$ acetyl-D-galactosamine and D-galactose.

To know the specificity between the lectins from host plants and cell surface polysaccharides from corresponding Rhizobia, the inhibitory activity of P-I, P-II and EXPS obtained from both $R$. japonicum 509 and $R$. legumino-

Table III. Minimum Concentration FOR INHIBITION OF SBA

\begin{tabular}{lc}
\hline Preparations & $\begin{array}{c}\text { Concentration } \\
(\mu \mathrm{mol} / \mathrm{ml})^{a}\end{array}$ \\
\hline CEP & 0.087 \\
P-I & 0.022 \\
P-II & 5.6 \\
D-Gal & 5.6 \\
GalNAc & 0.28 \\
\hline
\end{tabular}

a Calculated by amount of total carbohydrate with $\mathrm{D}$-glucose as a standard. 
sarum $\mathbf{J} 357$ against four kinds of lectin, SBA, $P A$, Con $A$ and WGA was measured respectively. As shown in Table IV, P-I from $R$. japonicum and $R$. leguminosarum has the strongest inhibition against the lectin obtained from the corresponding host plant, P-II also showed specific inhibition but was less active. There are reports that exopolysaccharide (capsular polysaccharide) is related to the symbiotic recognition; 8,15 , however, EXPS obtained from both $R$. japonicum and $R$. leguminosarum in this experiment showed no inhibitory activity against the lectin from corresponding host plants and the strongest against Con $\mathrm{A}$.

Table IV. Inhibitory Activity of Various POLYSACCHARIDES $(\mu \mathrm{mol} / \mathrm{ml})^{a}$ TOWARDS LeCtins ${ }^{b}$

\begin{tabular}{|c|c|c|c|c|c|}
\hline Species Pre & reparations & is SBA & PA & Con $\mathrm{A}$ & WGA \\
\hline R.japonicum & $n$ EXPS & - & - & 0.50 & - \\
\hline \multirow[t]{2}{*}{509} & P-I & 0.0065 & 0.052 & 0.21 & 0.052 \\
\hline & P-II 1 & 1.6 & 6.4 & $6.4 \sim 13$ & - \\
\hline R.legumi- & EXPS & - & - & 13 & $\ldots$ \\
\hline nosarum & P-I & 0.58 & $\begin{array}{r}0.14 \sim \\
0.29\end{array}$ & $\begin{array}{r}0.58 \sim \\
1.2\end{array}$ & 0.58 \\
\hline $\mathrm{J} 357$ & P-II & - & 11 & - & 23 \\
\hline
\end{tabular}

Inhibition of the binding reaction between lectin and Rhizobia. Equal volumes of fluorescent SBA (titer 256) and 509-P-I (6.7 $\mu \mathrm{mol} / \mathrm{ml}$ ) and also of fluorescent PA (titer 32) and J357-P-I $(4.6 \mu \mathrm{mol} / \mathrm{ml})$ were mixed and left still for $2 \mathrm{hr}$ at room temperature. Then, $R$. japonicum 509 and $R$. leguminosarum $\mathrm{J} 357$ were added to each mixture and examined under fluorescent microscope.

As is shown in Table II, SBA and PA, after preincubation with 509-P-I and J357-P-I respectively, were inhibited from binding to the corresponding Rhizobium.

\section{Lectin activity (hemagglutinating activity) of} roots of host plants

The host plants were grown in the biotron under the same conditions for tests of nodulating activity. The soybean roots were collected at 17 days and pea roots at 15 days after germination. The roots were ground in a blender and extracted overnight at $4^{\circ} \mathrm{C}$ with $0.155 \mathrm{M}$ saline and then concentrated with $90 \%$ saturated ammonium sulfate to obtain the crude extract. The activity of lectin in the root extract was measured using trypsinized rabbit erythrocyte suspension, and the existence of the lectin activity was confirmed (Table V).

Table V. HemagGlutinating Activity OF ROOT EXTRACTS

\begin{tabular}{ccc} 
Plants & $\begin{array}{c}\text { Titer }{ }^{a} \text { of 1\% } \\
\text { solution of lyo- } \\
\text { philized prepa- } \\
\text { rations }\end{array}$ & $\begin{array}{c}\text { Yield } \\
\text { g/100g } \\
\text { roots }^{b}\end{array}$ \\
\hline Soybean & 64 & 0.050 \\
Pea & 16 & 0.038 \\
\hline M Measured by using 3\% trypsinized rabbit ery- \\
throcyte suspension.
\end{tabular}

\section{DISCUSSION}

It is generally assumed that the specificity between the leguminous plants and Rhizobial species is due to the recognition and binding by Rhizobial cells of the specific materials existing on the root surface of corresponding host plants. Since Schmidt and Bohlool ${ }^{6 /}$ showed that 22 out of 25 strains of $R$. japonicum, but not other Rhizobial species, bound to soybean lectin labeled with FITC, lectins attracted attention as a probable component on the side of the plant in the process of symbiotic recogniton.

In this report, it was shown that (1) Rhizobia bound to lectin of the host plant, (2) LPS from the cell surface of Rhizobium played the role of the lectin-receptor in this reaction and (3) the LPS reacted specifically with the lectin of the host plant. These results support the lectin theory on the mechanism of specific recognition process in symbiotic nitrogen fixation of leguminous plants.

Incidentally, some reports against the lectin theory have been submitted. ${ }^{32 \sim 34)}$ However, it seems premature to deny immediately the role of lectins in the symbiont recognition process. The problems to be re-considered 
may include: the possibility of the tested lectin to be inadequate, the possibility of the lectinreceptor to change or disappear during the growth cycle of the bacteria, ${ }^{12)}$ and the effect of the difference in cultural and environmental conditions. ${ }^{35)}$ Another criticism against the lectin theory is that the lectin used was obtained from the seeds but not from the roots, to which Rhizobial cells bind. In this report, it is shown that the root has the lectin activity, although the chemical identity between the root and seed lectins or the interaction between the root lectin and the bacterial LFS have not yet been studied. Also, since there may be many kinds of sugar on the bacterial cell surface and some may easily bind to the lectin, it is possible for a certain Rhizobial cell to bind to the lectin of the plant other than its host. In this report, $R$. japonicum 509 bound also to pea lectin, and it may be possible, in considering some other evidences, to assume that the cell surface of this strain is modified to form a surface structure somewhat different from that of ordinary soybean Rhizobial strains and thus binds to pea lectin.

It is not always true that a Rhizobial cell starts symbiosis with a plant once it binds to the root hair of the plant. First, the difference in the strength and specificity of binding between lectin and bacteria is important in the establishment of recognition between a Rhizobium and a host. Second, although the binding of the Rhizobia to the root hair cells seems to be the most important factor in determining the host specificity, there are three additional stages to pass in the root nodule formation process; attraction of Rhizobial cells to the root hairs prior to binding, invasion following binding, and differentiation of bacterial cells to the bacteroids. Taking all these into consideration, it is more advisable to think that lectin is no more than one of the factors for deciding the host specificity.

Providing that lectins play an important role in the recognition process, a question will be raised-what is the lectin binding entity of $R h i$ zobial cells? There are two views on this problem; one assumes exopolysaccharide or capsular polysaccharide ${ }^{8,15)}$ and the other LPS. ${ }^{97}$ This report supports the latter view. P-II showed a specific interaction with the lectin in a similar way to that of $\mathrm{P}-\mathrm{I}$; however, P-II contained a small amount of polysaccharide degradation products of LPS in addition to the exopolysaccharides which could not be removed by saline-washing. Also, as shown in Table IV, the exopolysaccharide does not give a specific interaction with the lectin. P-I from $R$. leguminosarum J357 gave four bands in SDS-polyacrylamide gel electrophoresis. It is possible that there may be two kinds of LPS, one with the lectin-receptor activity and thus has a function in the host recognition process and the other without this activity. If it is true, this may be related to the fact that J357-P-I has a weaker activity than 509-P-I (Table IV). However, it is not excluded that the purified preparation of J357P-I still contains polysaccharides other than LPS. Further purification and analysis are needed to establish the lectin-lipopolysaccharide recognition hypothesis in leguminous root nodule formation process.

Acknowledgments. Thanks are due to Dr. T. Nishihara, Suntory Central Research Institute, Osaka, for helpful discussions, to Dr. S. Tsuru for the gift of Rhizobial strains and to Dr. Y. Nagata for the gift of lectins.

\section{REFERENCES}

1) P.H. Graham, "Symbiotic nitrogen fixation in plants," IBP 7, ed. by P. S. Nutman, Cambridge University Press, London, 1976, pp. 99

2) J. M. Vincent, "A Manual for the Practical Study of Root-Nodule Bacteria," IBP Handbook No.15, Blackwell Scientific Publications, Oxford and Edinburgh, 1970, p. 44.

3) G. M. W. Cook and P. W. Stoddart, "Saibô Hyôsô no Tôshitsu to Kinô," translated by K. Uchimi, University of Tokyo Press, University Peak Press, Tokyo, 1976, pp. 257 270.

4) W. F. Dudman, "Surface Carbohydrates of the Prokaryotic Cell," ed. by I. W. Sutherland, Academic Press Inc., (London) Ltd., 1977, p. 357.

5) P. Albersheim and A. J. Anderson, Ann. Rev. Plant Physiol., 26, 31 (1975).

6) B. B. Bohlool and E. L. Schmidt, Science., 185, 269 (1974). 
7) J. Hamblin and S. P. Kent, Nat. New Biol., 245, 28 (1974).

8) F. B. Dazzo and D. H. Hubbell, Appl. Microbiol., 30, 1017 (1975).

9) J. S. Wolpert and P. Albersheim, Biochem. Biophys. Res. Commun., 70, 729 (1976).

10) F. B. Dazzo, C. A. Napoli and D. H. Hubbell, Appl. Environ. Microbiol., 32, 166 (1976).

11) F. B. Dazzo and W. J. Brill, ibid., 33, 132 (1977).

12) T. V. Bhuvaneswari, S. G. Pueppke and W. D. Bauer, Plant Physiol., 60, 486 (1977).

13) F. B. Dazzo, W. E. Yanke and W. J. Brill, Biochim. Biophys. Acta, 539, 276 (1978).

14) K. Planque and J. W. Kinje, FEBS Lett., 73, 64 (1977).

15) H. E. Calvert, M. Lalonde, T. V. Bhuvaneswari and W. D. Bauer, Can. J. Microbiol., 23, 1274 (1978).

16) H. J. Evans, B. Koch and R. Klucas, "Methods in Enzymology," Vol. XXIV, ed. by S. P.Colowick and N.O. Kaplan, Academic Press Inc, New York, N.Y., 1972, p. 470.

17) J. M. Vincent, "A Manual for the Practical Study of Root-Nodule Bacteria," IBP Handbook No.15, Blackwell Scientific Publications, Oxford and Edinburgh, 1970, p. 77.

18) O. Westphal and K. Jann, "Methods in Carbo. hydrate Chemistry," Vol. V, ed. by R. L. Whistler, Academic Press Inc., New York, N.Y., 1965, p. 83.

19) B. Jann, K. Reske and K. Jann, Eur. J. Biochem., 60, 239 (1975).

20) R. M. Zacharius, T. E. Zell, J. H. Morrison and
J. J. Woodlock, Anal, Biochem, 30, 148 (1969).

21) H. Lis and N. Sharon, "Methods in Enzymology," Vol. XXVIII B, ed. by S. P. Colowick and N. O. Kaplan, Academic Press Inc., New York, N.Y., 1972, p. 360.

22) G. R. Gray, Arch. Biochim. Biophys, 163, 426 (1974).

23) H. J. Allen and E. A.Z. Johnson, Carbohydr. Res., 50, 121 (1976).

24) G. Entlicher, J. V. Koštiř and J. Kocourek, Biochim. Biophys. Acta, 221, 272 (1970).

25) B. J. Davis, Ann. N.Y. Acad. Sci., 121, 404 (1964).

26) A. Chrambach, R. A. Reisfeld, M. Wyckoff and J. Zaccari, Anal. Biochem., 20, 150 (1967).

27) M. Dubois, K. A. Gilles, K. J. Hamilton, P. A. Rebers and F. Smith, Nature., 168, 107 (1951).

28) A. Weissbach and J. Hurwitz, J. Biol. Chem., 234, 705 (1959).

29) O. H. Lowry, N. J. Rosebrough, A. L. Farr and R. J. Randall, J. Biol. Chem., 193, 265 (1951).

30) H. Lis, C. Fridman, N. Sharon and E. Katchalski, Arch. Biochem. Biophys., 117, 301 (1966).

31) N. Catsimpoolas and E.W. Meyer, Arch. Biochem. Biophys., 132, 279 (1969).

32) F. B. Dazzo and D. H. Hubbell, Plant Soil, 43, 717 (1975).

33) A. T. Chen and D. A. Phillips, Physiol. Plant., 38, 83 (1976).

34) I. J. Law and B. W. Strijdom, Soil Biol. Biochem., 9, 79 (1977).

35) T. V. Bhuvaneswari and W. D. Bauer, Plant Physiol., 62, 71 (1978). 